\title{
Developing Optimal Distinctive Open Innovation in Private Universities: Antecedents and Consequences on Innovative Work Behavior and Employee Performance
}

\author{
Luhgiatno Luhgiatno $^{1}$ \& Christantius Dwiatmadja ${ }^{1}$ \\ ${ }^{1}$ Faculty Economics and Business, Universitas Kristen Satya Wacana \\ Correspondence: Luhgiatno Luhgiatno, Faculty Economics and Business, Universitas Kristen Satya Wacana, \\ Indonesia.
}

Received: October 18, 2019

Accepted: June 22, 2020

Online Published: June 25, 2020

doi:10.5430/ijhe.v9n5p19

URL: https://doi.org/10.5430/ijhe.v9n5p19

\begin{abstract}
The purpose of this study is to analyze the effect of the concept of optimal distinctive open innovation as mediating variable in relationship between Person-Job Fit and Person-Organization Fit and work innovation behavior and lecturer performance. The method used in this study are through Structural Equation Modeling (SEM) analysis with the object of the study conducted on 193 lecturers determined by purposive random sampling technique at private universities in Central Java. The findings showed significant effects of person-organization fit on the optimal distinctive open innovation and on innovative work behavior. Moreover, person-job fit is of significant on optimal distinctive open innovation, and on innovative work behavior. In testing the effect of mediating variables, optimal distinctive open innovation is of significant on innovative work behavior which in turn affecting the significant influence of innovative work behavior on lecturer performance. The findings emphasize that the success-oriented way of thinking requires the expertise of employees to always create creative, superior and unique ideas. Private universities must always pay attention to the principles of industrial management and professionalism in human resource management, in order to survive and develop. Superior skills will produce superior performance, and superior skills are distinctive competence that supports the company to achieve positional advantage.
\end{abstract}

Keywords: optimal distinctive open innovation, person-job fit, person-organization fit, work innovation behaviour, lecturer performance

\section{Introduction}

A superior human resources management is expected to be able to maximize the contribution of the workforce in achieving organizational goals. The challenge faced by higher education institutions related to HR is related on the gap between recruitment and selection process with the level of alignment of individual work. Bowen et al. (1991) suggested that the conventional selection practice is to recruit employees who have the knowledge, skills and abilities (KSA) in accordance with certain job requirements. This practice ignores personal characteristics in recruitment, because personal characteristics are not relevant to certain job requirements which are more often called person-job fit (P-J fit) (Uzochukwu et al., 2018). Kristof-Brown and Billsberry (2012) describe person-job fit as work alignment at work, and this work alignment will ensure the effectiveness of work completion (WeiBo et al., 2010). Evidence from previous research findings concludes that the level of suitability of a person with work can affect work productivity and employee commitment (Kahya, 2009).

Furthermore, in the practice of selecting a new model, recruiting employees is carried out in full, reflected in the orientation of employees that are not only in accordance with the knowledge, skills and abilities (KSA) with job requirements, but must also match personal characteristics with organizational culture. This concept is called person-organization fit (P-O-fit). Moynihan and Pandey (2007) defines person-organization fit as a fit between an individual and an organization where at least there is a seriousness of employees to meet the needs of other parties, or individuals and organizations that have similar basic characteristics. Vianen et al. (2007) describe that people who are in accordance with the organization associate a person's personality, goals, and values with the organization. Organizations that are compatible with the values of employees, then they can increase their competitive advantage (Alajmi., 2016). 
The results of previous studies on the relationship between work suitability and work performance of personnel were found to be still diverse. In a separate study, person-job fit was found to be closely related to productivity and commitment (Rousseau \& McLean Parks, 1993), work performance (Greenberg, 2002), and had a positive effect on performance, job satisfaction, and reduction in work pressure and motivation (Edwards, 1991). When the compatibility of people with work and with the organizational environment is proven, it will increase job performance, even though the correlation has a weak tendency (Kristof - Brown et al., 2005). These findings contradict the findings of $\mathrm{Li} \&$ Hung (2010) in which person-job suitability was highly correlated to work performance.

Management of resources to produce innovative employees requires special attention. In this context, open innovation is considered to be able to develop well in the context of a system that emphasizes learning. To test this focus, this study takes the object of study open learning in the context of the performance of lecturers in tertiary institutions. Tertiary institutions are considered as an industry that produces and sells higher education or science services. Universities must pay attention to the principles of industrial management and professionalism in the management of human resources, in order to survive and develop. Conceptually, this study departed from the considerations that although previous studies prove that person-job fit can affect work performance, the number of studies related to this topic, especially to include the aspect of open innovation in higher education institutions, is still limited (Mosley, 2003). More specifically, this study would like to examine the role of innovation in lecturers expressed as a catalyst in improving innovative work behavior and lecturer work performance. This research was conducted at a private university in the Higher Education Service Institution (LLDikti) in Central Java, Indonesia.

\section{Literature Review}

\subsection{Work Innovation Behavior and Employee Performance}

Innovative work behavior is a physical and cognitive work activity carried out by employees in the context of their work, both alone and in groups to achieve a set of tasks with the aim of developing innovation (Messmann \& Mulder, 2011). Innovation is a gradual process with different activities and behaviors at each stage (Scott \& Bruce, 1994). Innovative work behavior makes employees pursue proactive behavior in the form of personal initiatives and new ideas that are directly related to effective performance in the organization (Afsar et al., 2015). Employee creative ideas can improve the performance of job supervisors (Brown \& Eisenhardt, 1995; Oldham \& Cummings, 1996). New ideas of innovation can take the form of new products, services, and improvements in existing procedures or processes as well as findings on alternative solutions that are efficient and effective for carrying out tasks (Zhou \& Shalley, 2003). Innovative ideas enable employees to improve personal work performance (Shalley et al., 2004). Based on these arguments, the proposed hypothesis is:

$H_{1}$ : There is an influence of innovative work behavior on employee performance.

\subsection{Optimal Distinctive Open Innovation and Innovative Work Behavior}

Optimal distinctive open innovation is a model of developing employee expertise to create superior and unique creative ideas, through different creativity, dynamic interactions, harmonizing cooperation, exchanging information, thinking without limits, and the complexity of relationships. Day \& Wensley (1988) explained that distinctive competence is a specific ability of an organization. Specific actions are carried out in order to perform activities better than its competitors, this is seen that the company has distinctive competence. There are two types of distinctive competence, namely: labor expertise and resource capabilities, (Day \& Wensley, 1988).

Superior expertise/skills will produce performance superiority. Superior skills are distinctive competencies that support the company to achieve positional advantages, and positional advantages which are expressed as performance outcomes which include customer satisfaction and loyalty. Employee innovative work behavior is analogous when good interpersonal relationships together with high-quality team member exchange relationships exist between colleagues (Janssen et al., 2004), as well as between work teams and organizational teams (Zakaria et al., 2004). The role of trust is intended to promote innovation in teams and/or carry out similar tasks to achieve predetermined organizational targets (Van der Vegt \& Janssen, 2003; Pudjiarti et al., 2017).

$\mathrm{H}_{2}$ : There is an influence of optimal distinctive open innovation on innovative work behavior.

\subsection{Person-Job Fit, Innovative Work Behavior and Open Innovation}

The concept of person-organization fit involves matching individual personality, values, goals, attitudes and needs with organizational values, demands and culture (Kristof-Brown \& Billsberry, 2012). The suitability of individual and organizational values helps change in the workplace (Lee \& Bang, 2012). Recognition related to the 
organizational context and environment in which individuals work and perform their duties in playing an important role is an innovative employee work behavior. person-organization fit refers to the suitability of the environment at the macro level while person-job fit involves matching individual skills, knowledge, and abilities with certain characteristics at the micro level within the scope of the organization and employees (Pudjiarti \& Hutomo, 2019).

Compatibility of a person with his environment, such as compatibility with work and organizational characteristics can be related to the level of innovative work behavior, and in the theory of adaptation-innovation shows that the interaction between people and their work choices determine their work attitude towards solving organizational problems. Superior skills will produce superior performance, and superior skills are distinctive competence that supports the company to achieve positional advantage. Overall employee work alignment is strongly related to a number of outcomes, including task performance (Hon \& Rensvold, 2006), problem solving (Harinck et al., 2000) and job satisfaction (Hon \& Rensvold, 2006), and organizational commitment and job performance (Kristor-Brown et al., 2005). Person-job fit plays an important role in influencing employees regarding their involvement in innovative work behavior through employee motivation.

$H_{3}$ : There is an influence of person-job fit on innovative work behavior

$\mathrm{H}_{4}$ : There is an influence of person-job fit on optimal distinctive open innovation

\subsection{Person-Organization Fit, Innovative Work Behavior and Open Innovation}

Vianen et al. (2007) in more detail explain person-organization fit from the perspective of supplementary fit and complementary fit. Supplementary fit occurs when an individual has characteristics (e.g preferences and attitudes) that are similar to characteristics possessed by other individuals in specific organizational environment. While complementary fit occurs if the characteristics possessed by individuals can be added to complement the characteristics not possessed by the organization concerned, individuals have to have special skills that are useful for increasing the success of a team work. This is associated with the concept of person-organization fit from Vianen et al. (2007), distinguishing person-organization fit from the perspective of supplies-values fit and demands-abilities fit.

The degree of suitability of an individual with the organization depends on the ability of the organization to meet the needs of employees. Meeting the needs of employees by organizations, such as compensation, working environment conditions and opportunities for progress are needed by employees, on the other hand, organizations need employee contributions in the form of commitment, expertise and ability (Wu \& Wu, 2017; Suparjo \& Sunarsih, 2018). Zhou et al. (2017) explain that in social identity theory, people tend to communicate with people who are similar in nature to them, which can increase their sense of belonging and happiness. Therefore, they have the confidence and enthusiasm to complete tasks, and improve performance. Stimulation theory shows that if organizations meet the needs of employees, they will feel compelled, they will make an effort to work, and improve performance. According to motivational theory, personal creativity can promote innovative ideas and behaviors. The suitability of the availability of employee needs significantly predicts employees' innovative behavior (Hernández et al., 2007). Different types of companies, different staff, and the suitability of the availability of needs to employee demands has a positive impact on innovation (Yao \& Fan, 2014).

$\mathrm{H}_{5}$ : There is an influence of person-organization fit on innovative work behavior.

$H_{6}$ : There is an influence of person-organization fit on optimal distinctive open innovation.

\section{Method}

This study uses primary data obtained through a questionnaire with the object of the lecturers in Higher Education Service Institution (LLDikti) VI Central Java, Indonesia. The number of samples taken was 193 lecturers determined by purposive random sampling technique. Measurement of variables using a Likert scale of 19 strongly disagree) to 79 strongly agree).

The measurement of person-job fit uses 5 indicators adapted from Cable \& DeRue (2002), namely: equality of expectations, suitability of needs, suitability of expertise, suitability of ability and suitability of education. Measurements of person-organization fit are formed by 4 indicators examined by Kristoff (1996), namely: appropriateness of values, appropriateness of objectives, fulfillment of needs, and conformity of culture. The measurement of innovative work behavior is measured by 4 indicators adopted from De Jong \& Den Hartog (2008), that are opportunity exploration, idea generation, becoming champions, and applicative capabilities. Optimal measurement of distinctive open innovation is measured by 6 indicators, namely creativity creates different values, dynamic interaction, harmonization of cooperation, exchange of information, thinking without limits and the complexity of relationships. Moreover, the lecturer performance is measured by 4 indicators adopted from Sukirno \& 
Sununta (2011) and Law No. 14/2005, namely teaching performance, individual or group research performance, publication performance, community service performance. Furthermore, hypothesis testing uses Structural Equation Modeling (SEM) as a tool to test the relationships between variables and obtain a comprehensive picture of the research model.

\section{Result}

\subsection{Dimensional Analysis, Reliability, and Validity}

The Kaiser Meyer Olkin (KMO) test results are seen above 0.70 and are significant. The size in EFA is if the value of the loading factor indicator is greater than the value of a particular factor, then these indicators can be grouped into variables (Table 1). Convergent validity was obtained that all indicators showed a significant loading factor $(\mathrm{p}<$ 0.01). Reliability of all latent variables is also higher than 0.7, this number is considered adequate (Hair et al., 1998). Likewise EVA value is higher than 0.5. Furthermore, testing the validity of the data is used to determine the extent of the accuracy and accuracy of a measurement instrument in carrying out its measurement function. While reliability shows how much the degree of measurement tests are consistent with the measured target.

Table 1. Data Suitability Testing

\begin{tabular}{|c|c|c|c|c|c|}
\hline Variable \& Indicator & Loading & KMO- Bartlett & $\begin{array}{l}\text { Cronbach's } \\
\text { Alpha }\end{array}$ & Reliability & $\begin{array}{l}\text { Variance } \\
\text { Extracted }\end{array}$ \\
\hline \multicolumn{6}{|l|}{ Person-Job Fit } \\
\hline 1. Similarity of expectations & 0.668 & \multirow{5}{*}{.852} & \multirow{5}{*}{0.845} & \multirow{5}{*}{.846} & .758 \\
\hline 2. Suitability of needs & 0.714 & & & & .781 \\
\hline 3. Suitability of expertise & 0.722 & & & & .778 \\
\hline Suitability of ability & 0.799 & & & & .828 \\
\hline 5. Suitability of education & 0.709 & & & & .785 \\
\hline \multicolumn{6}{|l|}{ Person-Organization Fit } \\
\hline 1. Suitability of value & 0.700 & \multirow{4}{*}{.785} & \multirow{4}{*}{0.801} & \multirow{4}{*}{.802} & .783 \\
\hline 2. Suitability of purpose & 0.713 & & & & .792 \\
\hline 3. Meeting the needs & 0.705 & & & & .801 \\
\hline 4. Suitability of culture & 0.720 & & & & .792 \\
\hline \multicolumn{6}{|l|}{ Optimal Distinctive Open Innovation } \\
\hline $\begin{array}{l}\text { 1. Creativity creates different } \\
\text { values }\end{array}$ & 0.711 & \multirow{6}{*}{.884} & \multirow{6}{*}{0.862} & \multirow{6}{*}{.815} & .768 \\
\hline 2. Dynamic interaction & 0.700 & & & & .765 \\
\hline $\begin{array}{l}\text { 3. Harmonization } \\
\text { cooperation }\end{array}$ & 0.695 & & & & .754 \\
\hline 4. Exchange of information & 0.701 & & & & .763 \\
\hline 5. Think without limits & 0.726 & & & & .778 \\
\hline 6. Complexity of relationships & 0.752 & & & & .789 \\
\hline \multicolumn{6}{|l|}{ Innovative Work Behavior } \\
\hline 1. Exploration of opportunities & 0.715 & \multirow{4}{*}{.768} & \multirow{4}{*}{0.836} & \multirow{4}{*}{.862} & .801 \\
\hline Idea generation & 0.753 & & & & .819 \\
\hline Become a champion & 0.792 & & & & .847 \\
\hline 4. Application ability & 0.733 & & & & .809 \\
\hline \multicolumn{6}{|l|}{ Lecturer Performance } \\
\hline 1. Teaching performance & 0.706 & \multirow{4}{*}{.0790} & \multirow{4}{*}{.813} & \multirow{4}{*}{.815} & .796 \\
\hline 2. Research performance & 0.691 & & & & .779 \\
\hline Publication performance & 0.765 & & & & .821 \\
\hline 4. Service performance & 0.733 & & & & .810 \\
\hline
\end{tabular}




\subsection{Respondent Characteristics}

The demographics of respondents show that majority were male (51.8\%). Most respondents aged 51 to 60 years (25.9\%) belong to the adult age and are not easily influenced by others in the selection of work, innovation, self-development, and knowledge development. Associated with the topic of this research on the optimal distinctive open innovation, the respondents have excellent potential in innovating because they are already very experienced, able to share knowledge and are aware of the need to improve performance as a lecturer. While seen from functional positions, most of them were lecturer assistant (34.7\%), lecturer (33.2\%), associate professor (31.1\%) and professors $(1 \%)$, the respondents surveyed need to improve their functional positions, because $67.9 \%$ are still below the associate professor. Meanwhile, when viewed from the working period, most have work experience above 15 years, so they already understand their duties and responsibilities as a lecturer. Respondents have the knowledge and experience to behave well, innovate and share knowledge and will ultimately be able to improve the work performance of lecturers.

\subsection{Goodness of Fit Model}

According to Joreskog and Sorbom (1989) to test the Structural Equation Modeling (SEM) model is done through a two-stage approach, namely the test of individual and simultaneous measurement models. Partial test was using the $t$ test, through the output of the t-values statistical path diagram. The results of the t-test were confirmed with a test error rate of 0.05 . The test results are significant if the $t$-value $<0.05$. Furthermore, overall model fit test in Structural Equation Modeling (SEM) is by matching between the sample covariance matrix and the estimated population covariance matrix.

Table 2. Goodness of Fit Model

\begin{tabular}{llll}
\hline Criteria of Fit & Cut-off-value & Result & Description \\
\hline Chi-Square & $<236.16$ & 201.481 & Fit \\
P-value & $>0.05$ & 0.092 & Fit \\
Goodness of Fit Index (GFI) & $>0.90$ & 0.903 & Fit \\
$\begin{array}{l}\text { Root Mean Square Error } \\
\text { Approximation (RMSEA) }\end{array}$ & $<0.08$ & 0.026 & Fit \\
$\begin{array}{l}\text { Adjusted GFI (AGFI) } \\
\text { Comparative Fit Index (CFI) }\end{array}$ & $>0.90$ & 0.880 & Marginal \\
Tucker-Lewis Index & $>0.90$ & 0.983 & Fit \\
Chi-Square/DF (Cmin/DF) & $<2.00$ & 0.981 & Fit \\
\hline
\end{tabular}

Table 2 showed that the resulting path model is declared fit because it is in the required cut-off values. Testing Structural Equation Modeling (SEM) assumptions, that the data have been declared normal both in the multivariate and univariate dimensions. Data is free from multivariate and univariate outlier data, and also free from multicollinearity and singularity.

\subsection{Hypothesis Testing}

The first hypothesis testing showed significant effect of person-organization fit to optimal distinctive open innovation with $\mathrm{CR}=3.859$ and sig. $=0.00>0.05$. This means that the higher the degree of person-organization fit that is felt by lecturers, the higher the level of optimal distinctive open innovation that can be produced by lecturers, making them more open in sharing knowledge. This supports the findings of Kriegesmann et al. (2007) found that when employees believe that their co-workers listen and support their ideas and relate their importance to suggestions for whatever novelty they start, they tend to display very innovative work behavior.

The second hypothesis testing showed the significant effect of person-job fit to optimal distinctive open innovation with $C R=4.276$ and sig.t $=0.00>0.05$. The results provide support for the acceptance of hypothesis, meaning that the higher the degree of alignment of the lecturers' work, the stronger the optimal distinctive open innovation. The results are in line with the findings of Messmann \& Mulder (2011) stating that innovative work behavior is a physical and cognitive work activity carried out by employees in the context of their work, both alone and in groups to achieve a set of tasks required with the aim of developing innovation.

Table 3. Regression Weights of Hypothesis Testing 


\begin{tabular}{llllll}
\hline Causality & Estimate & Std & S.E. & C.R. & $p$ \\
& & Estimate & & & \\
\hline Person organization fit $\rightarrow$ Distinctive open innovation & .360 & .329 & .093 & 3.859 & $* * *$ \\
Person Job Fit $\rightarrow$ Optimal distinctive open innovation & .353 & .368 & .083 & 4.276 & $* * *$ \\
Person organization fit $\rightarrow$ Innovative work behavior & .302 & .272 & .102 & 2.953 & .003 \\
Open innovation $\rightarrow$ Innovative work behavior & .253 & .249 & .096 & 2.629 & .009 \\
Person Job Fit $\rightarrow$ Innovative work behavior & .211 & .216 & .086 & 2.452 & .014 \\
Innovative work behavior $\rightarrow$ Lecturer performance & .350 & .368 & .088 & 3.986 & $* * *$
\end{tabular}

Statistical testing of third hypothesis showed the significant influence of person-organization fit on innovative work behavior with $C . R=2.952$ and $p=0.003>0.05$. This means that the higher the degree of person-organization fit felt by the lecturers, the higher the level of innovative work behavior. The results are in line with Yeşil \& Hırlak (2013) found that employees' perceptions about the climate and the innovative attractiveness of organizations to work arrangements and work assignments that are closer to their values, knowledge, skills and needs affect their involvement in behavior proactive and innovative. Kim et al. (2009) showed that suitability is related to employee perceptions about his assignment in working situations and that personal preferences will positively influence the results at the individual level, and make him more creative/innovative.

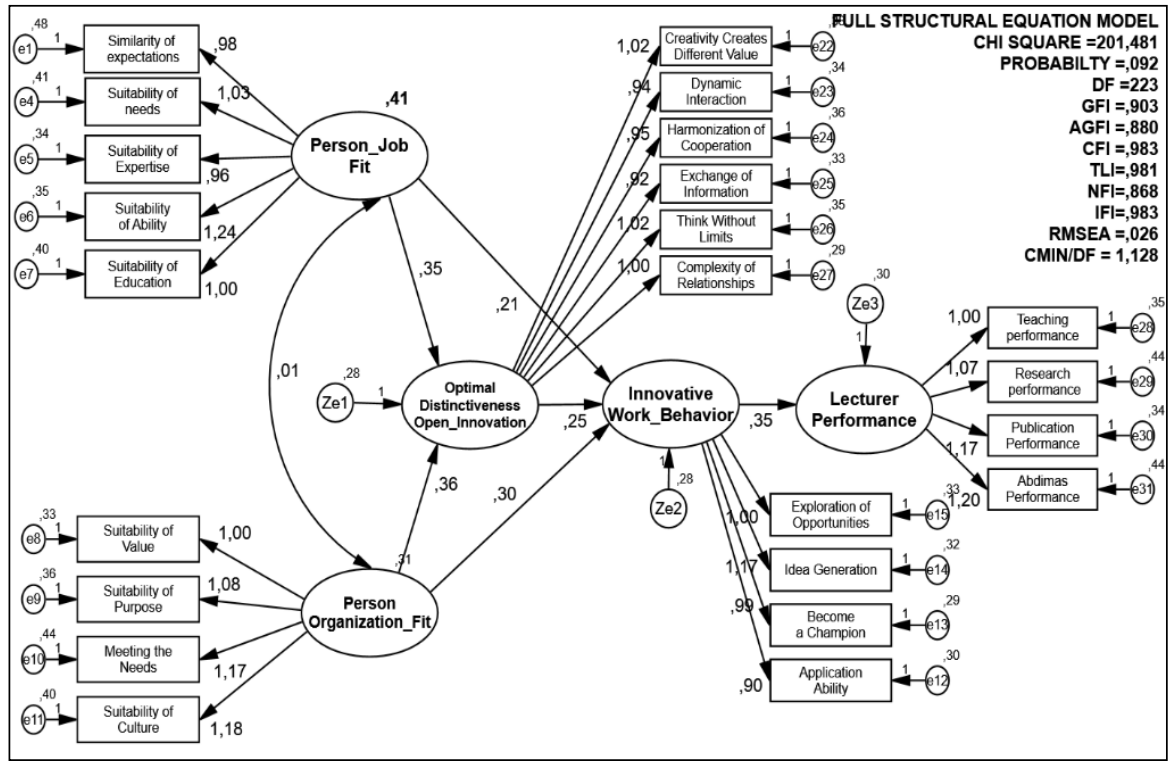

The effect of optimal distinctive open innovation on innovative work behavior was empirically proved significant with $\mathrm{CR}=2.629$ and $\mathrm{p}=0.009>0.05$, meaning that the higher the degree of optimal distinctive open innovation felt by the lecturers, the higher the level of innovative work behavior. With the complexity of relationships that tend to increase and the exchange of information that is fast and massive, requires lecturers to be accustomed to think out of the box in order to find new ideas in improving innovative work behavior. The exchange of information is often done in terms of exchange of material and administration of lectures, research and community service, collaboration between institutions and cooperation activities programs, publication of scientific papers, and the development of science and technology (Pudjiarti, 2018).

Testing the fifth hypothesis show a significant effect of person-job fit on innovative work behavior with $\mathrm{CR}=2.452$ and $\mathrm{p}=0.014>0.05$. This means that the higher the degree of person-organization fit felt by the lecturers, the higher the level of innovative work behavior. The results are in line with the findings of Yeşil \& Hırlak (2013) that employees' perceptions about the climate and the innovative attractiveness of organizations for work arrangements and assignments that are closer to their values, knowledge, skills and needs will influence their involvement in proactive and innovative behavior.

Statistical testing showed significant influence of innovative work behavior on lecturer performance with $\mathrm{CR}=3.986$ and sig. $=0.00>0.01$. This study explains that the higher the level of innovative work behavior felt by lecturers, the 
higher the lecturer performance. The results are in line with Shalley et al. (2004) found that innovative ideas enable employees to improve their personal work performance. Employee creative ideas can improve the performance of job supervisors (Brown \& Eisenhardt, 1995; Oldham \& Cummings, 1996). Empirical findings in the study indicate that lecturers contribute to doing creative things in exploring new opportunities for the growth of tertiary institutions. Their tendency is to explore new opportunities when carrying out duties and responsibilities in certain structural fields/positions. In general, the lecturers have a way of thinking that is oriented towards the continuous development of new discoveries. This idea can sustain its performance as a lecturer implementing objectives of higher education.

\section{Conclusions}

The study found the significant effect of person-organization fit to optimal distinctive open innovation and on innovative work behavior. There is also proved significant effects of person-job fit on optimal distinctive open innovation, and on innovative work behavior. Similarly, significant effect can be empirically proved on the relationship between optimal distinctive open innovation on innovative work behavior. Lastly, innovative work behavior is empirically significant on improving lecturer performance.

This indicates that the achievement of person-job fit and person-organization fit in organizations is to enable organizations and individuals to carry out a process of continuous improvement, through improving the quality of perspective and way of thinking. The main target of the person-job fit and person-organization fit process is the institutionalization of the collective knowledge possessed by members as a result of integration and sharing of knowledge and sharing of actual mental models in the form of strategies, programs, systems, or organizational guidelines. The ability of organizations to innovate that is unique and different is a prerequisite for the successful use of innovative human resources. With the innovations created, it is necessary to know how learning should be done to find information and knowledge that is able to create sustainable work behavior. The organization must develop the ability of its human resources to achieve the desired results. Hence, continuous learning is important for every individual.

\section{Limitations and Future Research Suggestions}

Limitations of this study are that it uses a cross-sectional approach, so the relationship between the concepts tested is a brief description of a particular time. In the future, it is proposed to conduct a longitudinal study because the performance of lecturers has further implications in the future, so that they can better assess the results of human resource development in the long term as an effort to improve lecturer performance. In future studies, it is suggested to add the concept of competitive advantage which is the goal of the organization.

\section{References}

Afsar, B., Badir, Y., \& Khan, M. M. (2015). Person-job fit, person-organization fit and innovative work behavior: The mediating role of innovation trust. The Journal of High Technology Management Research, 26(2), 105-116. https://doi.org/10.1016/j.hitech.2015.09.001

Alajmi, S. A. (2016). Organizational climate and its relationship to job satisfaction in Kuwaiti industrial companies. Asian Journal of Management Science and Economics, 3(2), 38-47.

Pudjiarti, E. S. (2017). Person Fit Organization (PO-Fit) Kunci Keunggulan Daya Saing Perguruan Tinggi Swasta Kota Semarang. Prosiding FEB UNTAG Semarang.

Bowen, D. E., Ledford Jr, G. E., \& Nathan, B. R. (1991). Hiring for the organization, not the job. Academy of Management Perspectives, 5(4), 35-51. https://doi.org/10.5465/ame.1991.4274747

Brown, S. L., \& Eisenhardt, K. M. (1995). Product development: Past research, present findings, and future directions. Academy of management review, 20(2), 343-378. https://doi.org/10.5465/amr.1995.9507312922

Cable, D. M., \& DeRue, D. S. (2002). The convergent and discriminant validity of subjective fit perceptions. Journal of applied psychology, 87(5), 875. https://doi.org/10.1037/0021-9010.87.5.875

Day, G. S., \& Wensley, R. (1988). Assessing advantage: a framework for diagnosing competitive superiority. Journal of marketing, 52(2), 1-20. https://doi.org/10.1177/002224298805200201

De Jong, J. P., \& Den Hartog, D. N. (2008). Innovative Work Behavior: Measurement and Validation. Zoetermeer: Scientific Analysis of Entrepreneurship and SMEs: SCALES. Unpublished Manuscript.

Edwards, J. R. (1991). Person-job fit: A conceptual integration, literature review, and methodological critique. John Wiley \& Sons. 
Greenberg, J. (2002). Time Urgency and Job Performance: Field Evidence of an Interactionist Perspective 1. Journal of Applied Social Psychology, 32(9), 1964-1973. https://doi.org/10.1111/j.1559-1816.2002.tb00267.x

Hair, J. F. J., Anderson, R. E., Tatham, R. L., \& Black, W. C. 1998. Multivariate Data Analysis, 5th edition, Upper Saddle River: Prentice Hall.

Harinck, F., De Dreu, C. K., \& Van Vianen, A. E. (2000). The impact of conflict issues on fixed-pie perceptions, problem solving, and integrative outcomes in negotiation. Organizational behavior and human decision processes, 81(2), 329-358. https://doi.org/10.1006/obhd.1999.2873

Hernández, P. M., Salanova, M., \& Peiró, J. M. (2007). Job demands, job resources and individual innovation at work: Going beyond Karasek s model?. Psicothema, 19(4), 621-626.

Hon, A. H., \& Rensvold, R. B. (2006). An interactional perspective on perceived empowerment: the role of personal needs and task context. The International Journal of Human Resource Management, 17(5), 959-982. https://doi.org/10.1080/09585190600641271

Janssen, O., \& Van Yperen, N. W. (2004). Employees' goal orientations, the quality of leader-member exchange, and the outcomes of job performance and job satisfaction. Academy of management journal, 47(3), 368-384. https://doi.org/10.5465/20159587

Jöreskog, K. G., \& Sörbom, D. (1989). A Guide to the Program and Applications. SPSS Inc, Chicogo.

Kahya, E. (2009). The effects of job performance on effectiveness. International Journal of Industrial Ergonomics, 39(1), 96-104. https://doi.org/10.1016/j.ergon.2008.06.006

Kim, T. Y., Hon, A. H., \& Crant, J. M. (2009). Proactive personality, employee creativity, and newcomer outcomes: A longitudinal study. Journal of Business and Psychology, 24(1), 93-103. https://doi.org/10.1007/s10869-009-9094-4

Kriegesmann, B., Kley, T., \& Schwering, M. G. (2007). Making organizational learning happen: The value of "creative failures". Business Strategy Series, 8(4), 270-276. https://doi.org/10.1108/17515630710684312

Kristof-Brown, A. L., \& Billsberry, J. (2012). Organizational fit: Key issues and new directions. John Wiley \& Sons. https://doi.org/10.1002/9781118320853

Kristof, A. L. (1996). Person-organization fit: An integrative review of its conceptualizations, measurement, and implications. Personnel psychology, 49(1), 1-49. https://doi.org/10.1111/j.1744-6570.1996.tb01790.x

Kristof-Brown, A. L. Zimmerman, \& RD, Johnson, EC (2005). Consequences of individuals' fit at work: A meta-analysis of person-job, personorganization, person-group, and person-supervisor fit. Personnel Psychology, 58(2), 281-342. https://doi.org/10.1111/j.1744-6570.2005.00672.x

Lee, J. W., \& Bang, H. (2012). High performance work systems, person-organization fit and organizational outcomes. Journal of Business Administration Research, l(2), 129. https://doi.org/10.5430/jbar.v1n2p129

Li, C. K., \& Hung, C. H. (2010). An examination of the mediating role of person-job fit in relations between information literacy and work outcomes. Journal of Workplace Learning,22(5), 306-318. https://doi.org/10.1108/13665621011053217

Messmann, G., \& Mulder, R. H. (2011). Innovative work behaviour in vocational colleges: Understanding how and why innovations are developed. Vocations and Learning, 4(1), 63-84. https://doi.org/10.1007/s12186-010-9049-y

Mosley, D. C. J. (2003). The influence of person-job fit, person-organization fit, and self-efficacy perceptions on work attitudes, job performance, and turnover.

Moynihan, D. P., \& Pandey, S. K. (2007). The ties that bind: Social networks, person-organization value fit, and turnover intention. Journal of public administration research and theory, 18(2), 205-227. https://doi.org/10.1093/jopart/mum013

Oldham, G. R., \& Cummings, A. (1996). Employee creativity: Personal and contextual factors at work. Academy of management journal, 39(3), 607-634. https://doi.org/10.5465/256657

Pudjiarti, E. S. (2018). Elements of entrepreneurship in private universities: Organizational change capacity, innovative capability and the performance. Journal of Entrepreneurship Education, 21(2), 1-15. 
Pudjiarti, E.S., \& Hutomo, P.T.P. (2019). Innovative work behavior: an integrative investigation of person-job fit, person-organzation fit and person-group fit. Business Theory and Practice 20. https://doi.org/10.3846/btp.2020.9487

Rousseau, D. M., \& McLean Parks, J. (1993). The contracts of individuals and organizations. Research in organizational behavior, 15, 1-1.

Scott, S. G., \& Bruce, R. A. (1994). Determinants of innovative behavior: A path model of individual innovation in the workplace. Academy of management journal, 37(3), 580-607. https://doi.org/10.2307/256701

Shalley, C. E., Zhou, J., \& Oldham, G. R. (2004). The effects of personal and contextual characteristics on creativity: Where should we go from here? Journal of management, 30(6), 933-958. https://doi.org/10.1016/j.jm.2004.06.007

Sukirno, D. S., \& Siengthai, S. (2011). Does participative decision making affect lecturer performance in higher education?. International Journal of Educational Management, 25(5), 494-508. https://doi.org/10.1108/09513541111146387

Suparjo, S., Sunarsih, E. S., \& Sakdiyah, A. (2018). Optimalisasi Kinerja Melalui Kualitas Kehidupan Kerja, Karakteristik Pekerjaan, Dan Kepuasan Kerja (Studi pada Aparatur Sipil Negara Sekretariat Daerah Kabupaten Jepara). Serat Acitya, 7(1), 28.

Uzochukwu, O. C., Obiageli, O. L., Jonathan, O. R., \& Olohi, E. S. (2018). Job embeddedness and employee performance in selected oil and gas companies in Bayelsa state of Nigeria. African Journal of Business Management, 12(2), 34-43. https://doi.org/10.5897/AJBM2017.8466

Van der Vegt, G. S., \& Janssen, O. (2003). Joint impact of interdependence and group diversity on innovation. Journal of management, 29(5), 729-751. https://doi.org/10.1016/S0149-2063_03_00033-3

Van Vianen, A. E., De Pater, I. E., \& Van Dijk, F. (2007). Work value fit and turnover intention: same-source or different-source fit. Journal of managerial psychology, 22(2), 188-202. https://doi.org/10.1108/02683940710726438

WeiBo, Z., Kaur, S., \& Zhi, T. (2010). A critical review of employee turnover model (1938-2009) and development in perspective of performance. African Journal of Business Management, 4(19), 4146-4158.

Wu, C., \& Wu, G. (2017, January). Person-organization fit relationship with innovative performance of employees: A literature review. In 2017 International Conference on Education, Culture and Social Development (ICECSD 2017). Atlantis Press. https://doi.org/10.2991/icecsd-17.2017.41

Yao, Y. H., \& Fan, Y. Y. (2014). The impact of person-organization fit on innovative behavior-the moderating effects of Zhongyong thinking and Chaxu climate. East China Economic Management, 28(11), 123-127.

Yeşil, S., \& Hırlak, B. (2013). An empirical investigation into the influence of knowledge sharing barriers on knowledge sharing and individual innovation behaviour. International Journal of Knowledge Management (IJKM), 9(2), 38-61. https://doi.org/10.4018/jkm.2013040103

Zakaria, N., Amelinckx, A., \& Wilemon, D. (2004). Working together apart? Building a knowledge-sharing culture for global virtual teams. Creativity and innovation management, 13(1), 15-29. https://doi.org/10.1111/j.1467-8691.2004.00290.x

Zhou, H. Y., Gao, B. B., \& Wu, J. (2017). Sunrise or sunset: Selective comparison learning for subtle attribute recognition. arXiv preprint arXiv:1707.06335. https://doi.org/10.5244/C.31.129

Zhou, J., \& Shalley, C. E. (2003). Research on employee creativity: A critical review and directions for future research. In Research in personnel and human resources management, 165-217. Emerald Group Publishing Limited. https://doi.org/10.1016/S0742-7301(03)22004-1 